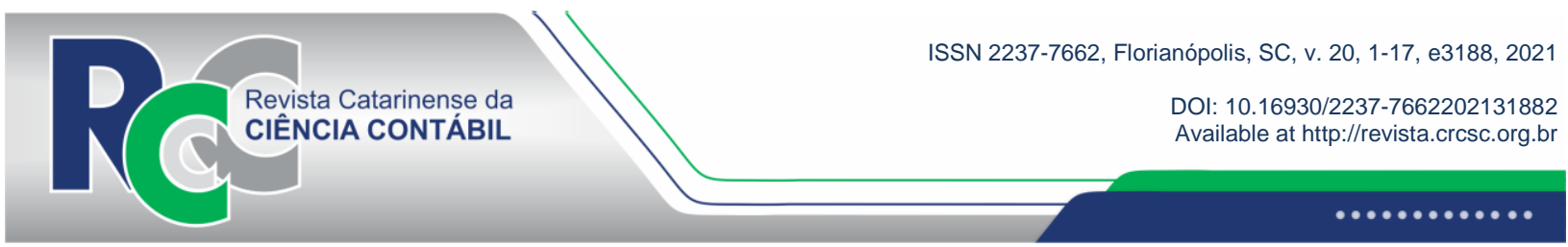

\title{
EQUITY LIQUIDITY AND TAX AGGRESSIVENESS IN THE BRAZILIAN CAPITAL MARKET
}

\author{
BERNARDO FERNANDES LOTT PRÍMOLA \\ Federal University of Minas Gerais. Address: Av. Presidente Antônio \\ Carlos, 6627| Pampulha | 31270-090 | Belo Horizonte/MG | Brazil. \\ (D) https://orcid.org/0000-0002-6028-2156 \\ bernardoflprimola@gmail.com
}

\section{EDUARDO MENDES NASCIMENTO}

Federal University of Minas Gerais. Address: Av. Presidente Antônio Carlos, 6627 | Pampulha | 31270-090 | Belo Horizonte/MG | Brazil.

(D) http://orcid.org/0000-0002-2188-9748

e.mn@uol.com.br

\section{OCTÁVIO VALENTE CAMPOS}

Federal University of Minas Gerais. Address: Av. Presidente Antônio Carlos, 6627 | Pampulha | 31270-090 | Belo Horizonte/MG | Brazil.

(D) https://orcid.org/0000-0002-0354-0796

octaviovc@yahoo.com.br

\begin{abstract}
This study has investigated the potential relationship between equity liquidity and tax aggressiveness in the Brazilian capital market. Using a database of publicly traded Brazilian companies from 2010 to 2019 - not including the year 2020 due to the atypical effects of the COVID-19 pandemic - panel data models have been developed, the goal synthesis of which consisted in evaluating the longitudinal effects of equity liquidity, independent variable, on the book tax difference, dependent variable, and proxy of tax aggressiveness. Results have shown a statistically significant and economically positive relationship between the tax aggressiveness proxy and stockholding liquidity. Results suggests that companies with less volatile stocks, with larger relative stocks in B3 [(in full, B3 - Brasil Bolsa Balcão S.A.), formerly BM\&FBOVESPA, a stock exchange located at São Paulo, Brazil] businesses and lower trading costs tend to adopt a more aggressive tax planning. This article helps to demonstrate that in an emerging capital market such as the Brazilian one investor tend to belittle occasional increases in profits sparingly through more aggressive tax practices, however, which may result in future losses. Furthermore, this study
\end{abstract}

Edited in Portuguese and English. Original version in Portuguese.

Research funded by the Research Support Foundation of the State of Minas Gerais - FAPEMIG.

Received on 7/16/2021. Reviewed on 9/30/2021. Accepted on 10/13/2021 by the Prof. PhD Sérgio Murilo Petri (Editor-Chief) and Prof. PhD Sandro Vieira Soares (Deputy Editor). Published on 11/12/2021.

Copyright ( 2021 RCCC. All Rights Reserved. It is allowed to quote part of articles without prior authorization, provided that the source is identified. 
helps to demonstrate the importance of disclosures about tax planning so that market agents can properly price financial assets.

Keywords: Tax Aggressiveness. Equity Liquidity. Informational asymmetry. Disclosure.

\section{INTRODUCTION}

The main objective of this study was to evaluate potential correlations between the liquidity of publicly traded Brazilian companies and the tax aggressiveness proxy. All this because, according to Hanlon and Heitzman (2010), tax aggressiveness is defined as an explicit reduction in the tax burden on profit. It is appropriate to establish in advance that the concept of tax aggressiveness is not to be confused with the idea of tax evasion since the essence of this concept stems from the execution of strictly legal activities and efficient planning, which cause the reduction of the explicit tax burden, increasing the business returns (Chen, Chen, Cheng and Shevlin, 2010; Scholes, Wolfson, Erickson, Maydew and Shevlin, 2014).

Furthermore, the different tax aggressiveness proxies can capture natural effects of the accounting and fiscal practices and procedures that are not related to planning. While some proxies only focus on tax planning, others also capture earnings management. This difference is due to the inconsistency between financial accounting and tax accounting, which have different frameworks for handling certain specific issues (Formigoni, Antunes and Paulo, 2009; Hanlon and Heitzman, 2010; Martinez and Leal, 2019).

Subject to the above limitations, the study of the tax burden on the profit of publicly traded companies is an opportune activity since, although reductions in the taxation on profit may increase net profits, previous literature has mapped that investors tend to carefully analyze such increases due to the possibility of associating tax aggressiveness with the increase in information asymmetry between internal and external agents (Wahab and Holland, 2012).

Besides, Wahab and Holland (2012) indicate that tax aggressiveness on some occasions may result from the tax administration planning or conducts that are not fully disclosed in corporate reports. Therefore, tax aggressiveness can result in greater difficulties in projecting a company's cash flows in addition to hiding certain risks of assessments by tax authorities (Cao and Wan, 2014).

In this context, it is expected that market agents monitor publicly traded corporations to obtain relevant information to price equity instruments about tax planning so that this monitoring is greater for stocks with greater liquidity (Bebchuk and Weisbach, 2010; Chen, Ge, Louis and Zolotoy, 2019).

Within the scope of the Brazilian capital market, it is possible to verify an expansion in the amount of studies evaluating potential tax aggressiveness practices, more specifically under the presence of different levels of financial leverage (Martinez and Martins, 2016) considering the relationship with related parties (Martinez and Dalfior, 2015) in addition to taking as a reference the corporate governance systems idiosyncrasy (França and Monte, 2019).

That said, the present study has aimed to answer the following research problem: How does stock liquidity influence the tax aggressiveness of publicly traded Brazilian companies listed in B3 (Brasil, Bolsa e Balcão)? Thus, this research has the objective of evaluating potential practical signs of tax aggressiveness vis-à-vis the shareholding liquidity of publicly traded Brazilian companies.

This study is justified for three reasons. The first one refers to the high volatility of capital markets in emerging countries such as the Brazilian market (Lahrech and Sylwester, 2011; Al 
Nasser and Hajilee, 2016; Mclver and Kang, 2020). And therefore, it is important to pay attention to signals that can influence this volatility.

The second reason is due to the role of stock liquidity as a way of minimizing information asymmetry. Stock liquidity can have a surveillance effect on the companies' fiscal policy by monitoring possible abusive practices of tax aggressiveness, that is, tax evasion (Cao and Wan, 2014; Chen et al., 2019). Stock liquidity improves stock price informativeness because the value of shareholder intervention in the company's management, and consequently in the inspection of fiscal policies, is reflected in stock prices more quickly when the stock is liquid and can also cause an increase in stock value. This generates a cycle in which shareholders perceive the benefits of this intervention when the stocks are more liquid, which further encourages shareholders' interventions (Chen and Zolotoy, 2014; Chen et al., 2019).

The third justification for this study is related to the different characteristics of direct taxes in Brazil, among which: they have greater complexity in the tax system, greater competitive advantage by not adopting full disclosure, permission to use the payment of interest on equity as deductibility from the IRPJ (Brazilian corporate income tax) calculation basis, among others that can even encourage tax evasion (Almeida Júnior, 2007; Santos, Carvalho, and Ávila, 2019).

Furthermore, the results of this study reinforce the importance of wide dissemination of tax management practices since such disclosures have the power to reduce any bolder tax planning which, although they may result in an increase in present profits, may culminate in future reductions of cash flows. This reduction is due to tax assessments and costs of legal consultants to mitigate potential consequences of these tax assessments (Hanlon and Heitzman, 2010; Blaylock, Shelvin and Wilson, 2012; Vello and Martinez, 2014).

\section{LITERATURE REVIEW AND HYPOTHESIS DEVELOPMENT}

\subsection{Tax aggressiveness and its distinctions from the concept of tax evasion}

A company has several instruments that can be used to reduce its tax burden (Martinez and Dalfior, 2015). For this reason, it is essential to distinguish what tax planning is and what tax evasion is, which is even an act prohibited by national laws. Thus, tax aggressiveness does not imply illegality and in many cases, it is even desired and encouraged.

Hanlon and Heitzman (2010) define tax aggressiveness as an explicit reduction in income taxes. In this line, Lisowsky, Robinson and Schmidt (2013) characterize tax aggressiveness as activities at the end of the tax minimization continuum. Slemrod and Yitzhaki (2002) emphasize that the distinguishing feature between tax aggressiveness and tax evasion is the illegality of the latter concept.

Still regarding tax evasion, Frischmann, Shevlin and Wilson (2008) define it as engaging in significant fiscal positions with relatively weak supporting facts. As for tax aggressiveness, adopting the understanding that it is a completely legal activity, Chen et al. (2010) defines it as a managerial reduction of taxable income by means of tax planning actions.

It is important to remember that tax planning involves a set of factors that help to reduce explicit taxes, if they are applied within corporate governance practices and under a legal framework (Vello and Martinez, 2014; Tôrres, 2001).

Scholes et al. (2014) maintain that tax planning results from a set of actions aimed at promoting the reduction of explicit taxes, not adding other costs or taxes with marginal effects greater than the reductions achieved, thus generating greater tax efficiency.

A few years ago, Brazil implemented anti-avoidance provisions in the National Tax Code by which tax authorities have managed to combat and discourage taxpayers' acts of artificial or elusive tax avoidance (Martinez and Ramalho, 2017). 


\subsection{Stock liquidity}

Stock liquidity is a multidimensional measure that has several transactional characteristics such as: tightness, depth, resiliency, immediacy, and breadth (Kyle, 1985; Amihud, 2002; Sarr and Lybek, 2002; Lesmond, 2005; Menezes da Silva, 2009; Vieira, Justen Junior and Righi, 2015). This multidimensional scope allowed the use of different metrics, some of which are related to trading activity (turnover) while others are linked to trading values (bid-ask spread) (Machado and Medeiros, 2012).

Holmström and Tirole (1993) have studied the value of the stock market as a managerial performance monitor. They have identified that the bid-ask spread is determined only by the trading frequency of liquidity traders, that is, long-term traders do not tend to influence the discount on spot prices.

Bhattacharya, Desai and Venkataraman (2013) have investigated the association between quality of stock earnings and information asymmetry in a sample of NYSE (New York Stock Exchange) and NASDAQ (National Association of Securities Dealers Automated Quotations) companies from 1998 to 2007. The authors identified that the low quality of earnings is significantly associated with greater information asymmetry.

Menezes da Silva (2009) has identified the relationship between stock liquidity and the level of disclosure of publicly traded Brazilian companies in the steel and metallurgy sector in the period between 1998 and 2007. The liquidity variables and disclosure of information show a positive relationship in general. The author indicated that it is preferable to invest in stocks of companies that maintain an information disclosure policy aimed at reducing information asymmetry. The lack of knowledge due to lack of information results in lower stock liquidity and higher cost of capital.

Another factor that affects stock liquidity is the role of insider trading (Chung, Goh, Lee and Shevlin, 2019). Jayaraman and Milbourn (2012) have investigated whether the role of stock liquidity influences the composition of the CEO's annual salary and the sensitivity of managerial wealth to stock prices. The study has pointed out that companies with greater stock liquidity depend less on the cash-based remuneration of managers as part of the total remuneration of annual contracts. Additionally, they concluded that reliance on stock prices in the preparation of executives' compensation is greater for companies with greater liquidity.

In the specific scope of the Brazilian capital market, Machado, and Medeiros (2012) have analyzed the existence by means of the following variables: turnover, traded volume, number of trades, negotiability (liquidity on the stock exchange) and standardized turnover. Machado and Medeiros (2012) have concluded that there is a liquidity "premium" in the Brazilian market and that corporate policies can smooth out liquidity costs, that is, they improve the liquidity of securities by reducing the cost of capital and increasing the company's value.

These corporate policies also aim to provide more voluntary information to the market, reducing information asymmetry and the risk perceived by stakeholders (Amihud and Mendelson, 2006). In this way, the principals can benefit from this new information, adopting them as a surveillance mechanism for agents.

That said, it is possible to conjecture the following hypothesis:

$\mathrm{H}_{1}$ Market liquidity inhibits tax aggressiveness practices as a greater volume of information on the tax administration of companies with greater shareholder liquidity is required. 


\section{METHODOLOGICAL APPROACHES}

\subsection{Study Data and Sample}

The data used in this study were obtained from the Economatica ${ }^{\circledR}$ platform and comprise non-financial Brazilian companies listed on B3 in the period between 2010 and 2019. This period was chosen because 2009 was the last year after the transition period from Brazilian accounting standards to international standards. According to Martinez and Silva (2017), this change has favored the effect of comparability among the companies' financial statements.

Furthermore, the year 2020 was not included due to the COVID-19 pandemic, the effects of which are still being assimilated and understood on the time series of financial markets, above all due to economic paralysis. Financial companies were excluded due to their characteristics and particularities in relation to tax legislation (Famá and French, 1992; Machado and Medeiros, 2012; França and Monte, 2019).

Observations with missing data and outliers were excluded, respectively. Outliers were identified using the Quartile Method on the dependent variable, as described by Oliveira, Caroli, Amaral and Vilca (2014). Then, 5\% winsorization was applied, as described by Tukey (1962). In the end, 1304 observations from 232 companies resulted.

\subsection{Variables}

In this study we have chosen to use the Book-Tax Differences (BTD) as a metric representing the dependent variable Tax Aggressiveness, especially because this is a metric widely used in the literature, which seeks to analyze the tax aggressiveness behavior as well as for this metric being able to capture normative distinctions of accounting profit vis-à-vis tax profit (Carvalho, Paulo, and Tavares, 2014).

Mills (1998) defines Book-Tax Differences (BTD) as accounting income before tax minus taxable income, that is, accounting income minus taxable income.

$$
B T D_{i t}=L A I R_{i t}-\left(\frac{I R / C S L L L_{i t}}{0,34}\right)
$$

Compelling the BTD dependent variable to the other predictive terms of its statistical behavior it is possible to establish the model for testing Hypothesis (1) as follows in Equation (2) below.

$$
\begin{gathered}
\text { BTD }_{i t}=\alpha+\beta_{1} \cdot \text { Vol }_{i t}+\beta_{2} \cdot \text { Liqb }_{i t}+\beta_{3} \cdot \text { Qneg }_{i t}+\beta_{4} \cdot \text { Qtit }_{i t}+\beta_{5} \cdot \text { Turn }_{i t}+\beta_{6} \cdot \text { Tur }_{i t}+\beta_{7} \cdot \text { Sprd }_{i t} \\
+ \text { Variáveis de Controle }+\varepsilon_{i t}
\end{gathered}
$$

The independent variables of stock liquidity - terms of interest - are shown in Table 1. The Liquidity variable is not directly observable and has several aspects that cannot be captured by a single measure. Therefore, to test the research hypothesis, using variables that capture the multidimensionality of stock liquidity was chosen (Amihud, 2002; Menezes da Silva, 2009; Vieira et al., 2015). 
Table 1

\section{Independent variables of interest}

\begin{tabular}{|c|c|c|c|c|}
\hline Name & Symbol & Description & $\begin{array}{l}\text { Expected } \\
\text { Signal }\end{array}$ & Reference \\
\hline $\begin{array}{l}\text { Financial } \\
\text { Volume }\end{array}$ & VOL & $\begin{array}{c}\text { Financial volume of a traded } \\
\text { asset over a period of one } \\
\text { year }\end{array}$ & $(-)$ & $\begin{array}{l}\text { Brennan, Chordia and Subrahmanyam } \\
\text { (1998); Lesmond (2005); Vieira and Milach } \\
\text { (2008); Menezes da Silva (2009); Vieira et } \\
\text { al. (2015); Machado and Medeiros (2012); } \\
\text { Perobelli, Famá and Sacramento (2016); } \\
\text { Silveira, Vieira, Bender Filho and Coronel } \\
\text { (2017). }\end{array}$ \\
\hline $\begin{array}{l}\text { Liquidity } \\
\text { on the stock } \\
\text { exchange }\end{array}$ & LIQB & $100 x\left(\frac{p}{P}\right) x \sqrt{\frac{n}{N} x \frac{v}{V}}$ & $(-)$ & $\begin{array}{l}\text { Menezes da Silva (2009); Machado and } \\
\text { Medeiros (2012); Martins and Paulo (2014); } \\
\text { Silva, Nardi, Martins and Barossi Filho } \\
\text { (2016). }\end{array}$ \\
\hline $\begin{array}{l}\text { Number of } \\
\text { deals }\end{array}$ & QNEG & $\begin{array}{l}\text { Number of occurrences of } \\
\text { purchase and sale of an asset } \\
\text { in a year }\end{array}$ & $(-)$ & $\begin{array}{l}\text { Vieira and Milach (2008); Menezes da Silva } \\
\text { (2009); Machado and Medeiros (2012); } \\
\text { Vieira, Justen Junior and Righi (2015); } \\
\text { Silveira et al. (2017). }\end{array}$ \\
\hline $\begin{array}{c}\text { Number of } \\
\text { securities }\end{array}$ & QTIT & $\begin{array}{c}\text { Number of shares traded in } \\
\text { one year }\end{array}$ & $(-)$ & $\begin{array}{l}\text { Vieira and Milach (2008); Menezes da Silva } \\
\text { (2009); Silveira et al. (2017). }\end{array}$ \\
\hline Turnover 1 & TUR1 & $\frac{\text { QTIT }}{\text { Average share price } \text { pr }_{t}}$ & $(-)$ & $\begin{array}{l}\text { Vieira and Milach (2008); Menezes da Silva } \\
\text { (2009); Perobelli, Famá and Sacramento } \\
(2016) \text {. }\end{array}$ \\
\hline Turnover 2 & TUR2 & 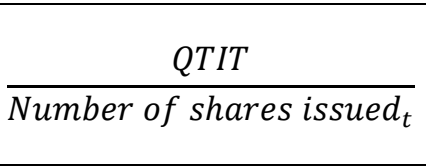 & $(-)$ & $\begin{array}{l}\text { Datar, Naik and Radcliffe (1998); Menezes } \\
\text { da Silva (2009); Vieira et al. (2015); } \\
\text { Perobelli, Famá and Sacramento (2016); } \\
\text { Silveira et al. (2017). }\end{array}$ \\
\hline $\begin{array}{l}\text { Maximum } \\
\text { and } \\
\text { minimum } \\
\text { spread }\end{array}$ & SPRD & $100 x\left(\frac{\text { Max Price }- \text { Min Price }}{\text { Average Price }}\right)$ & $(+)$ & $\begin{array}{l}\text { Vieira and Milach (2008); Menezes da Silva } \\
\text { (2009); Vieira et al. (2015); Perobelli, Famá } \\
\text { and Sacramento (2016); Silva et al. (2016). }\end{array}$ \\
\hline
\end{tabular}

Legend: $\mathrm{p}=$ number of days in which there was at least one share deal; $\mathrm{P}=$ total number of days; $\mathrm{n}=$ number of deals with the action; $\mathrm{N}=$ number of trades with all shares; $\mathrm{v}=$ cash volume with the stock; $\mathrm{V}=$ cash volume with all shares; QTIT $=$ number of shares traded in a year.

The control variables are in Table 2. The choice of these variables was conceived based on previous studies, which also evaluated equity liquidity, however with different objectives from those explored in this study.

Table 2

\section{Control variables}

\begin{tabular}{|c|c|c|c|c|}
\hline Name & Symbol & Description & $\begin{array}{l}\text { Expected } \\
\text { Signal }\end{array}$ & Reference \\
\hline Availabilities & CASH & $\frac{\text { Cash and Cash Equivalents }_{t}}{\text { Total Assets }_{t-1}}$ & + & $\begin{array}{l}\text { Chen and Zolotoy (2014); Chen et al. } \\
\text { (2019); Chiachio and Martinez } \\
\text { (2019). }\end{array}$ \\
\hline Equity Income & EQUIV & $\frac{{\text { Equity } \text { Income }_{t}}_{\text {Total Assets }} \text { t-1 }}{\text { Tot }^{2}}$ & -+ & $\begin{array}{l}\text { Nakao (2012); McGuire, Wang and } \\
\text { Wilson (2014); Chen and Zolotoy } \\
\text { (2014); Brunozi, Kronbauer, } \\
\text { Martinez \& Alves (2018); Chen } \text { et al. } \\
\text { (2019). }\end{array}$ \\
\hline Company Size & SIZE & $\ln (\text { Total Assets })_{t}$ & + & $\begin{array}{l}\text { Rego (2003); Chen and Zolotoy } \\
\text { (2014); Cao and Wan (2014); } \\
\text { Gaertner (2014); Martins and } \\
\text { Paulo (2014); Chen and Lin (2017); }\end{array}$ \\
\hline
\end{tabular}




\begin{tabular}{|c|c|c|c|c|}
\hline & & & & $\begin{array}{l}\text { Chen et al. (2019); Chiachio and } \\
\text { Martinez (2019); França and Monte } \\
\text { (2019). }\end{array}$ \\
\hline Intangible asset & INTAG & $\frac{{\text { Intangible } \text { Assets }_{t}}_{\text {Total Assets }}}{\text { As-1 }}$ & +- & $\begin{array}{l}\text { Chen and Zolotoy (2014); Cao and } \\
\text { Wan (2014); Gaertner (2014); Chen et } \\
\text { al. (2019); Chiachio and Martinez } \\
\text { (2019); Melo, Castro Moraes, Souza } \\
\text { and Nascimento (2020). }\end{array}$ \\
\hline Index & ALAV & 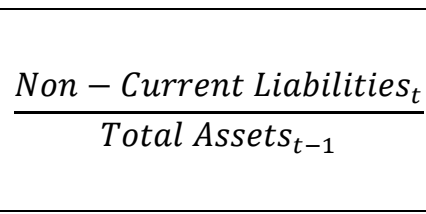 & + & $\begin{array}{l}\text { Chen and Zolotoy (2014); Cao and } \\
\text { Wan (2014); Gaertner (2014); Chen et } \\
\text { al. (2019); Chiachio and Martinez } \\
\text { (2019); França and Monte (2019); } \\
\text { Moraes et al. (2021). }\end{array}$ \\
\hline Fixed assets & IMOB & $\frac{\text { Fixed } \text { Assets }_{t}}{\text { Total Assets }_{t-1}}$ & + & $\begin{array}{l}\text { Chen and Zolotoy (2014); Cao and } \\
\text { Wan (2014); Chen and Lin (2017); } \\
\text { Chen et al. (2019); Chiachio and } \\
\text { Martinez (2019); Melo et al. (2020). }\end{array}$ \\
\hline Return on Assets & ROA & $\frac{\text { LAIR }_{t}}{\text { Total Assets }_{t-1}}$ & + & $\begin{array}{l}\text { McGuire et al. (2014); Chen and } \\
\text { Zolotoy (2014); Cao and Wan (2014); } \\
\text { Gaertner (2014); Chen et al. (2019); } \\
\text { Chiachio and Martinez (2019); } \\
\text { França and Monte (2019). }\end{array}$ \\
\hline $\begin{array}{l}\text { Return on Assets } \\
\text { Variation }\end{array}$ & SROA & $R O A_{t}-R O A_{t-1}$ & - & $\begin{array}{l}\text { Chen and Zolotoy (2014); Gaertner } \\
\text { (2014); Chen et al. (2019). }\end{array}$ \\
\hline
\end{tabular}

Legend: - CASH: defined as Cash and Cash Equivalent for the year divided by the total asset of the previous year, as it is a control variable for the company's cash level; - Equity Income (EQUIV): defined as the Equity Income for the year divided by the total Assets of the previous year. Controls the investment activities of companies (extracted from consolidated statements); - Company Size (SIZE): the natural logarithm of the total asset of the year is used. Controls tax avoidance cost policy; - Intangible Assets (INTAG): total intangibles of the year divided by the total assets of the previous year. Along with IMOB, controls the company's ability to protect income through depreciation and amortization; - Leverage (ALAV): total Non-Current Liabilities for the year divided by the total Asset of the previous year. Controls the effect of long-term debt; - Fixed Assets (IMOB): total assets in the year divided by the total assets of the previous year. Along with INTAG, controls the company's ability to protect income through depreciation and amortization; - Return on Assets (ROA): defined as the LAIR of the year divided by the total Asset of the previous year. Controls the profitability of the company; - Return on Assets Variation (SROA): ROA for the current year minus the PREVIOUS YEAR's ROA divided by the total Asset of the previous year. Along with ROA, controls the profitability and uncertainties in the company's operation.

In favor of statistical robustness of the parameters estimated in this material, Equation (2) was estimated through the different existing approaches about panel data models. Thus, to determine which of the regression models is the most adjusted, the Chow, Hausman and LM tests of Breusch-Pagan were used.

\section{PRESENTATION AND ANALYSIS OF RESULTS}

The main descriptive statistics are described in Table 3. Among the main metrics to characterize the distribution of the BTD variable, the Kurtosis coefficient $(\mathrm{k}>3)$ stands out, which indicates that the BTD variable is Leptokurtic. This finding shows signs of a long tail effect (Chissom, 1970). This result may indicate that companies with more aggressive or conservative proxies can have significant impacts due to the concentration of greater severity.

The Skewness coefficient $(\mathrm{v}<0)$ indicates that the left tail is heavier and that therefore there is an asymmetry in the data. This indicates that there is a greater number of companies in the first quartile of the sample. The Stock Exchange Liquidity Index, Number of Trades and Number of Securities variables have similar statistical behavior when analyzing the sample distribution. The Stock Exchange Liquidity Index, in turn, has a median and mean that are very close, 0.0123 
and 0.1395 , which indicates greater normality in the sample distribution. However, the data variability in the sample remains high as the standard deviation is 0.2496 and the Q3-Q1 amplitude is 0.1549 .

Analysis of the variables Number of Trades and Number of Securities leads to a similar result. The mean and median of both variables have a similar value: 333,683.30 and 34,870.00, respectively, for the Number of Trades and 144,549.10 and 17,731.47, respectively, for the variable Number of Securities.

When comparing the values of the measures of central tendency with the values of amplitude, it is noticed that there is a concentration of data closer to the values of Q1 than to the values of Q3. When analyzing the values of the means and medians with the maximum and minimum values, a data cloud is found much closer to the minimums than to the maximums.

Table 3

\section{Descriptive statistics of data}

\begin{tabular}{|c|c|c|c|c|c|c|c|c|c|}
\hline Var. & Average & $\begin{array}{c}\text { Standard } \\
\text { Deviation }\end{array}$ & Min. & Max & Q1 & Q2 & Q3 & $\begin{array}{c}\text { Skewn } \\
\text { ess } \\
\end{array}$ & $\begin{array}{c}\text { Kurto } \\
\text { sis } \\
\end{array}$ \\
\hline BTD & 13 thousand & $\begin{array}{l}130 \\
\text { thousand }\end{array}$ & $\begin{array}{l}-440 \\
\text { thousand }\end{array}$ & $\begin{array}{c}340 \\
\text { thousand }\end{array}$ & $\begin{array}{r}-26 \\
\text { thousand }\end{array}$ & $\begin{array}{c}7.6 \\
\text { thousa } \\
\text { nd }\end{array}$ & 70 thousand & -0.53 & 4.79 \\
\hline Cash & 0.08 & 0.09 & - & 0.39 & 0.01 & 0.05 & 0.12 & 1.58 & 5.28 \\
\hline $\begin{array}{c}\text { Equi } \\
\mathrm{V}\end{array}$ & - & - & -0.01 & 0.01 & - & - & - & 0.95 & 9.08 \\
\hline Size & 14.27 & 1.69 & 9.85 & 17.23 & 13.3 & 14.41 & 15.46 & -0.51 & 2.96 \\
\hline Intag & 0.15 & 0.2 & - & 0.78 & - & 0.04 & 0.23 & 1.53 & 4.41 \\
\hline Alav & 0.42 & 0.4 & 0.03 & 2.23 & 0.18 & 0.33 & 0.52 & 2.83 & 12.47 \\
\hline Imob & 0.26 & 0.23 & - & 0.87 & 0.04 & 0.22 & 0.4 & 0.83 & 2.85 \\
\hline ROA & 0.06 & 12.43 & -48.9 & 18.49 & -2.15 & 2.49 & 6.51 & -2.09 & 8.47 \\
\hline $\begin{array}{c}\text { SRO } \\
\text { A }\end{array}$ & - & - & - & - & - & - & - & - & 13.51 \\
\hline VOL & $\begin{array}{c}2,100 \\
\text { thousand }\end{array}$ & $\begin{array}{c}4,100 \\
\text { thousand }\end{array}$ & 240 & $\begin{array}{r}18,000 \\
\text { thousand }\end{array}$ & $\begin{array}{c}11 \\
\text { thousand }\end{array}$ & $\begin{array}{c}160,00 \\
0\end{array}$ & $\begin{array}{c}2,000 \\
\text { thousand }\end{array}$ & 2.58 & 9.28 \\
\hline $\begin{array}{c}\text { LIQ } \\
\text { B }\end{array}$ & 0.14 & 0.25 & - & 1.02 & - & 0.01 & 0.15 & 2.16 & 6.93 \\
\hline $\begin{array}{c}\text { QNE } \\
\text { G }\end{array}$ & $\begin{array}{c}330 \\
\text { thousand }\end{array}$ & 580,000 & 59 & $\begin{array}{r}2,400 \\
\text { thousand }\end{array}$ & $\begin{array}{c}2.3 \\
\text { thousand }\end{array}$ & $\begin{array}{c}35 \\
\text { thousa } \\
\text { nd }\end{array}$ & $\begin{array}{l}400 \\
\text { thousand }\end{array}$ & 2.12 & 6.84 \\
\hline $\begin{array}{l}\text { QTI } \\
\text { T }\end{array}$ & $\begin{array}{l}140 \\
\text { thousand }\end{array}$ & $\begin{array}{c}270 \\
\text { thousand }\end{array}$ & 6.4 & $\begin{array}{r}1,200 \\
\text { thousand }\end{array}$ & 900 & $\begin{array}{c}18 \\
\text { thousa } \\
\text { nd }\end{array}$ & $\begin{array}{l}160 \\
\text { thousand }\end{array}$ & 2.53 & 9.03 \\
\hline $\begin{array}{c}\text { TUR } \\
1\end{array}$ & 18 thousand & 36 thousand & 0.15 & $\begin{array}{r}170 \\
\text { thousand }\end{array}$ & 110 & $\begin{array}{c}2.5 \\
\text { thousa } \\
\text { nd }\end{array}$ & 16 thousand & 2.91 & 11.26 \\
\hline $\begin{array}{c}\text { TUR } \\
2\end{array}$ & 0.58 & 0.64 & - & 2.74 & 0.08 & 0.37 & 0.85 & 1.53 & 5.05 \\
\hline $\begin{array}{c}\text { SPR } \\
\text { D }\end{array}$ & 0.84 & 0.73 & 0.22 & 3.65 & 0.4 & 0.58 & 0.94 & 2.31 & 8.21 \\
\hline
\end{tabular}

This result demonstrates once again that there is a preference for trading certain stocks in the Brazilian market and that these stocks have large amounts of securities, large amounts of trades and move a high financial volume, which is typical of a concentrated market.

Finally, the Number of Trades variable presents high multicollinearity at a significance level of $1 \%$ with the variable Number of Securities, 0.8353 , corroborating the results found by 
Menezes da Silva (2009), strengthening the thesis that liquidity is multidimensional and that it is not directly observable, requiring multiple measures for this (Amihud, 2002; Menezes da Silva, 2009; Vieira et al., 2015).

Table 4

Pearson correlation analysis

\begin{tabular}{|c|c|c|c|c|c|c|c|c|c|c|c|c|c|c|c|c|}
\hline Var. & 1 & 2 & 3 & 4 & 5 & 6 & 7 & 8 & 9 & 10 & 11 & 12 & 13 & 14 & 15 & 16 \\
\hline $1 \mathrm{BTD}$ & 1 & & & & & & & & & & & & & & & \\
\hline $2 \mathrm{CASH}$ & $\underline{0.08}$ & 1 & & & & & & & & & & & & & & \\
\hline 3 EQUIV & $\underline{0.1}$ & 0.03 & 1 & & & & & & & & & & & & & \\
\hline 4 SIZE & $\underline{0.13}$ & $\underline{0.16}$ & $0.06^{* *}$ & 1 & & & & & & & & & & & & \\
\hline 5 INTAG & $\underline{0.08}$ & $\underline{0.11}$ & -0.02 & $\underline{0.3}$ & 1 & & & & & & & & & & & \\
\hline 6 ALAV & $\underline{-0.14}$ & -0.02 & -0.03 & $\underline{-0.23}$ & 0.01 & 1 & & & & & & & & & & \\
\hline 7 IMOB & -0.04 & 0.02 & $-0.05^{*}$ & 0.01 & $\underline{-0.28}$ & $\underline{0.17}$ & 1 & & & & & & & & & \\
\hline $8 \mathrm{ROA}$ & $\underline{0.46}$ & $\underline{0.23}$ & $0.07 * *$ & $\underline{0.37}$ & $\underline{0.19}$ & $\underline{-0.36}$ & $-0.06^{* *}$ & 1 & & & & & & & & \\
\hline 9 SROA & 0.04 & 0.03 & -0.01 & 0.01 & 0.02 & $0.07 * *$ & 0.03 & $\underline{0.25}$ & 1 & & & & & & & \\
\hline $10 \mathrm{VOL}$ & $\underline{0.14}$ & $\underline{0.16}$ & $\underline{0.07}$ & $\underline{0.52}$ & $\underline{0.2}$ & $-0.05^{*}$ & -0.03 & $\underline{0.2}$ & 0 & 1 & & & & & & \\
\hline $11 \mathrm{LIQB}$ & $\underline{0.14}$ & $\underline{0.16}$ & $\underline{0.07}$ & $\underline{0.55}$ & $\underline{0.2}$ & $-0.05 *$ & -0.03 & $\underline{0.21}$ & 0 & $\underline{0.96}$ & 1 & & & & & \\
\hline 12 QNEG & $\underline{0.11}$ & $\underline{0.15}$ & $\underline{0.09}$ & $\underline{0.56}$ & $\underline{0.19}$ & $-0.05 *$ & $-0.05^{* *}$ & $\underline{0.19}$ & 0 & $\underline{0.89}$ & $\underline{0.95}$ & 1 & & & & \\
\hline 13 QTIT & $\underline{0.15}$ & $\underline{0.15}$ & $\underline{0.14}$ & $\underline{0.49}$ & $\underline{0.15}$ & -0.01 & -0.04 & $\underline{0.15}$ & 0 & $\underline{0.81}$ & $\underline{0.84}$ & $\underline{0.83}$ & 1 & & & \\
\hline 14 TUR1 & $\underline{0.07}$ & $\underline{0.1}$ & $\underline{0.15}$ & $\underline{0.37}$ & $0.06^{* *}$ & 0 & $\underline{-0.08}$ & $\underline{0.08}$ & 0 & $\underline{0.48}$ & $\underline{0.55}$ & $\underline{0.58}$ & $\underline{0.84}$ & 1 & & \\
\hline 15 TUR2 & $-0.05 *$ & -0.01 & -0.02 & $\underline{0.13}$ & $0.05^{*}$ & 0.03 & $\underline{-0.16}$ & $\underline{-0.07}$ & 0.01 & $\underline{0.43}$ & $\underline{0.46}$ & $\underline{0.48}$ & $\underline{0.4}$ & $\underline{0.35}$ & 1 & \\
\hline 16 SPRD & $\underline{-0.3}$ & $\underline{-0.19}$ & $-0.06^{* *}$ & $\underline{-0.29}$ & $\underline{-0.13}$ & $\underline{0.19}$ & -0.04 & $\underline{0.46}$ & 0.01 & $\underline{-0.16}$ & $\underline{-0.16}$ & $\underline{-0.16}$ & $\underline{-0.15}$ & $-0.06^{* *}$ & $\underline{0.26}$ & 1 \\
\hline
\end{tabular}

Legend: [underline] $=$ Significant at $1 \% ;[* *]=$ Significant at $5 \% ;[*]=$ Significant at $10 \%$.

Regarding the most suitable model, the Chow Test indicated the fixed effects model $(\mathrm{F}=$ 4.26, Prob $>\mathrm{F}=0.000$ ). The Hausman Test confirmed the indication of the fixed effects model (chi $2=12.90$, Prob $>$ chi $2=0.2292$ ). Finally, the Breusch-Pagan LM Test indicated the predilection of the random effects model (chi-bar $2=238.13$, Prob $>$ chi-bar $2=0.0000$ ). Due to the crossed indications regarding the best estimation format of the panel data models, applying both techniques, fixed effects, and random effects, was chosen (Table 5).

The Fixed Effects Model with Cluster presents because of F-test the value of 6.4830, while the Fixed Effects Model presents the value of 23.3524 (Table 5). Based on the results of the Ftests, it is concluded that the best estimation approach is the fixed effects technique.

Table 5

Comparison of Panel Data Models

\begin{tabular}{c|rrrrrr}
\hline Var. & \multicolumn{1}{|c}{ POOL } & \multicolumn{1}{c}{ PROBS } & \multicolumn{1}{c}{ EF } & \multicolumn{1}{c}{ EFCLUST } & \multicolumn{1}{c}{ EA } & \multicolumn{1}{c}{ EACLUS } \\
\hline \multirow{2}{*}{ CASH } & $-67,890.32$ & $-67,890.32$ & $-51,886.47$ & $-51,886.47$ & $-67,649.63$ & $-67,649.63$ \\
& $(35,050.29)$ & $(45,084.83)$ & $(44,989.35)$ & $(71,342.26)$ & $(39,554.31)$ & $(55,245.60)$ \\
\hline \multirow{2}{*}{ EQUIV } & $2,350,622.70$ & $2,350,622.70$ & $3,309,387.30$ & $3,309,387.30$ & $3,112,367.50$ & $3,112,367.50$ \\
& $(946,350.47)$ & $(1,424,967,50)$ & $(1,009,618.10)$ & $(1,346,898.50)$ & $(935,775.33)$ & $(1,289,642.30)$ \\
\hline \multirow{2}{*}{ SIZE } & $-7,473.14$ & $-7,473.14$ & $-21,758.15$ & $-21,758.15$ & $-9,868.00$ & $-9,868.00$ \\
& $(2,528.28)$ & $(4,191.05)$ & $(9,164.18)$ & $(12,608.07)$ & $(4,157.36)$ & $(5,206.38)$ \\
\hline \multirow{2}{*}{ INTAG } & $-7,576.09$ & $-7,576.09$ & $-26,444.28$ & $-26,444.28$ & $-12,250.11$ & $-12,250.11$ \\
& $(17,167.07)$ & $(26,539.57)$ & $(41,231.40)$ & $(62,636.02)$ & $(25,305.19)$ & $(30,028.98)$ \\
\hline
\end{tabular}




\begin{tabular}{|c|c|c|c|c|c|c|}
\hline ALAV & $\begin{array}{r}12,390.21 \\
(8,861.43)\end{array}$ & $\begin{array}{r}12,390.22 \\
(13,277.47)\end{array}$ & $\begin{array}{r}16,440.59 \\
(14,824.39) \\
\end{array}$ & $\begin{array}{r}16,440.59 \\
(18,248.25) \\
\end{array}$ & $\begin{array}{r}19,558.21 \\
(11,464.29) \\
\end{array}$ & $\begin{array}{r}19,558.21 \\
(14,091.28) \\
\end{array}$ \\
\hline IMOB & $\begin{array}{r}-13,627.13 \\
(14,527.36)\end{array}$ & $\begin{array}{r}-13,627.13 \\
(21,005.30) \\
\end{array}$ & $\begin{array}{r}5,747.18 \\
(32,767.11) \\
\end{array}$ & $\begin{array}{r}5,747.18 \\
(42,364.22) \\
\end{array}$ & $\begin{array}{r}-9,807.63 \\
(21,465.59) \\
\end{array}$ & $\begin{array}{r}-9,807.63 \\
(24,348.99) \\
\end{array}$ \\
\hline ROA & $\begin{array}{r}4,967.23 \\
(335.76) \\
\end{array}$ & $\begin{array}{r}4,967.23 \\
(684.82)\end{array}$ & $\begin{array}{l}5,322.41 \\
(362.28) \\
\end{array}$ & $\begin{array}{r}5,322.41 \\
(835.34) \\
\end{array}$ & $\begin{array}{l}5,329.01 \\
(335.55)\end{array}$ & $\begin{array}{l}5,329.01 \\
(755.74) \\
\end{array}$ \\
\hline SROA & $\begin{array}{r}-1,3 \mathrm{E}+08 \\
(4.4 \mathrm{E}+07)\end{array}$ & $\begin{array}{r}-1,3 \mathrm{E}+08 \\
(5.7 \mathrm{E}+07)\end{array}$ & $\begin{array}{r}-1,3 \mathrm{E}+08 \\
(3.8 \mathrm{E}+07)\end{array}$ & $\begin{array}{r}-1,3 \mathrm{E}+08 \\
(6.1 \mathrm{E}+07)\end{array}$ & $\begin{array}{r}-1,3 \mathrm{E}+08 \\
(3.7 \mathrm{E}+07)\end{array}$ & $\begin{array}{r}-1,3 \mathrm{E}+08 \\
(6.0 \mathrm{E}+07)\end{array}$ \\
\hline VOL & $\begin{array}{r}-0.00 \\
(0.00) \\
\end{array}$ & $\begin{array}{r}-0.00 \\
(0.01) \\
\end{array}$ & $\begin{array}{r}-0.00 \\
(0.00) \\
\end{array}$ & $\begin{array}{r}-0.00 \\
(0.00) \\
\end{array}$ & $\begin{array}{r}-0.00 \\
(0.00) \\
\end{array}$ & $\begin{array}{r}-0.00 \\
(0.00) \\
\end{array}$ \\
\hline LIQB & $\begin{array}{r}84,615.48 \\
(67,557.67) \\
\end{array}$ & $\begin{array}{r}84,615.48 \\
(116,869.81) \\
\end{array}$ & $\begin{array}{r}121,598.58 \\
(71,283.30) \\
\end{array}$ & $\begin{array}{r}121,598.58 \\
(124,598.22) \\
\end{array}$ & $\begin{array}{r}99,427.32 \\
(63,008.95) \\
\end{array}$ & $\begin{array}{r}99,427.32 \\
(104,572.91) \\
\end{array}$ \\
\hline QNEG & $\begin{array}{r}-0.05 \\
(0.02) \\
\end{array}$ & $\begin{array}{r}-0.05 \\
(0.03) \\
\end{array}$ & $\begin{array}{r}-0.01 \\
(0.02) \\
\end{array}$ & $\begin{array}{r}-0.01 \\
(0.04) \\
\end{array}$ & $\begin{array}{r}-0.03 \\
(0.02) \\
\end{array}$ & $\begin{array}{r}-0.03 \\
(0.03) \\
\end{array}$ \\
\hline QTIT & $\begin{array}{r}0.16 \\
(0.04) \\
\end{array}$ & $\begin{array}{r}0.16 \\
(0.06) \\
\end{array}$ & $\begin{array}{r}-0.04 \\
(0.06) \\
\end{array}$ & $\begin{array}{r}-0.04 \\
(0.09) \\
\end{array}$ & $\begin{array}{r}0.13 \\
(0.05) \\
\end{array}$ & $\begin{array}{r}0.13 \\
(0.07) \\
\end{array}$ \\
\hline TUR1 & $\begin{array}{r}-0.54 \\
(0.21) \\
\end{array}$ & $\begin{array}{l}-0.54 \\
(0.33) \\
\end{array}$ & $\begin{array}{l}-0.85 \\
(0.24) \\
\end{array}$ & $\begin{array}{l}-0.85 \\
(0.38) \\
\end{array}$ & $\begin{array}{l}-0.78 \\
(0.22) \\
\end{array}$ & $\begin{array}{l}-0.78 \\
(0.36) \\
\end{array}$ \\
\hline TUR2 & $\begin{array}{r}-835.65 \\
(6,242.12) \\
\end{array}$ & $\begin{array}{r}-835.64 \\
(9,854.28) \\
\end{array}$ & $\begin{array}{r}12,345.07 \\
(8,308.59) \\
\end{array}$ & $\begin{array}{r}12,345.07 \\
(11,851.40)\end{array}$ & $\begin{array}{r}1,246.52 \\
(7,020.43) \\
\end{array}$ & $\begin{array}{r}1,246.51 \\
(9,719.84) \\
\end{array}$ \\
\hline SPRD & $\begin{array}{r}-17,646.63 \\
(5,262.56) \\
\end{array}$ & $\begin{array}{r}-17,646.63 \\
(5,954.10) \\
\end{array}$ & $\begin{array}{r}-14,881.67 \\
(5,081.60) \\
\end{array}$ & $\begin{array}{r}-14,881.67 \\
(5,494.84) \\
\end{array}$ & $\begin{array}{r}-15,924.06 \\
(4,847.58) \\
\end{array}$ & $\begin{array}{r}-15,924.06 \\
(5,358.17) \\
\end{array}$ \\
\hline _cons & $\begin{array}{r}134,058.97 \\
(35,903.94) \\
\end{array}$ & $\begin{array}{r}134,058.97 \\
(58,501.09) \\
\end{array}$ & $\begin{array}{r}336,721.57 \\
(128,528.69) \\
\end{array}$ & $\begin{array}{r}336,721.57 \\
(178,645.90) \\
\end{array}$ & $\begin{array}{r}165,118.77 \\
(58,630.21)\end{array}$ & $\begin{array}{r}165,118.77 \\
(71,737.81) \\
\end{array}$ \\
\hline $\mathrm{N}$ & $1,304.0$ & $1,304.00$ & $1,304.00$ & $1,304.00$ & $1,304.00$ & $1,304.00$ \\
\hline $\mathrm{R}^{2}$ & 0.2544 & 0.2544 & 0.2489 & 0.2489 & - & - \\
\hline $\mathrm{R}_{-}^{2} \mathrm{O}$ & - & - & 0.1322 & 0.1322 & 0.2445 & 0.2445 \\
\hline $\mathrm{R}_{-}^{2} \mathrm{~B}$ & - & - & 0.0423 & 0.0423 & 0.1971 & 0.1971 \\
\hline $\mathrm{R}_{-}^{2} \mathrm{~W}$ & - & - & 0.2489 & 0.2489 & 0.2368 & 0.2368 \\
\hline F & 29.29 & 7.95 & 23.35 & 6.48 & - & - \\
\hline Q2 & - & - & - & - & 391.30 & 109.51 \\
\hline sigma_u & - & - & $114,809.35$ & $114,809.35$ & $84,166.52$ & 84166.52 \\
\hline sigma_e & - & - & $90,031.39$ & $90,031.39$ & $90,031.39$ & $90,031.39$ \\
\hline rho theta & - & - & 0.6192 & 0.6192 & 0.4664 & 0.4664 \\
\hline
\end{tabular}

Legend: $\mathrm{POOL}=$ Pooled; $\mathrm{PROBS}=$ Pooled with Cluster; $\mathrm{EF}=$ Fixed Effects; EFCLUST $=$ Fixed Effects with Cluster; $\mathrm{EA}=$ Random Effects; EACLUS $=$ Clustered Random Effects.

Nonsignificant variables from the model were removed with the purpose of attenuating possible effects of multicollinearity on the result by using the Stepwise technique (Fávero, 2015). The technique consists of the gradual subtraction of the variables that presented the worst result in the p-value. $p$-value at the significance level of $1 \%$ was adopted as significant for the model, resulting in the final model shown in Table 6.

Autocorrelation was verified using the Wooldridge Test, which presented F (1.172) of 0.920 and Prob $>$ F of 0.3387 . Based on this result, the null hypothesis of absence of autocorrelation is not accepted.

This model presented a coefficient of determination $\left(\mathrm{R}^{2}\right)$ of 0.1535 at a significance level of $1 \%$. This result demonstrates that stock liquidity is related to the tax aggressiveness proxies of 
companies in the Brazilian stock market. This result is consistent with the study by Chen et al. (2019), which has found a similar value of $\mathrm{R}^{2}(0.149)$ in an OLS (ordinary least squares) Regression and values between 0.16 and 0.23 for quartiles between $10 \%$ and $40 \%$ in a Quartile Regression Analysis.

Table 6

Significant predictors in the Fixed Effects Model

\begin{tabular}{l|rrrrrr}
\hline \multicolumn{1}{c}{ VAR. } & \multicolumn{1}{c}{ COEF } & \multicolumn{1}{c}{ STD. ERR } & \multicolumn{1}{c}{ T } & \multicolumn{1}{c}{$\mathrm{P}>|\mathrm{t}|$} & \multicolumn{2}{c}{$95 \%$ Confidence Interval } \\
\hline EQUIV & $3,146,476.00$ & $995,158.80$ & 3.16 & 0.002 & $1,193,781.00$ & $5,099,170.00$ \\
SIZE & $-25,833.58$ & $8,398.82$ & -3.08 & 0.002 & $-42,309.78$ & -9357.38 \\
ROA & $5,263.98$ & 351.78 & 14.96 & 0.000 & $4,573,706.00$ & $5,954.25$ \\
SROA & $-1.21 \mathrm{e}+08$ & $3.76 \mathrm{e}+07$ & -3.23 & 0.001 & $-1.95 \mathrm{e}+08$ & $-4.77 \mathrm{e}+07$ \\
LIQB & $86,101.25$ & $30,140.70$ & 2.86 & 0.004 & $26,959.25$ & $145,243.20$ \\
TUR1 & -0.87 & 0.18 & -4.80 & 0.000 & -1.23 & -0.52 \\
SPRD & $-13,317.87$ & $4,953.39$ & -2.69 & 0.007 & $-23,037.39$ & $-3,598.34$ \\
CONST & $394,503.90$ & $118,958.80$ & 3.32 & 0.001 & $161,083.7$ & $627,924.10$ \\
\hline
\end{tabular}

\begin{tabular}{|c|c|c|c|}
\hline $\mathrm{N}$ & 1,304 & Rho & 0.6059 \\
\hline $\mathrm{R}^{2}$ within & 0.2448 & $\mathrm{~F}(6.1066)$ & 49.32 \\
\hline $\mathrm{R}^{2}$ between & 0.0695 & Prob $>F$ & 0.00 \\
\hline $\mathrm{R}^{2}$ overall & 0.1535 & corr $\left(\mathrm{u} \_\mathrm{i}, \mathrm{Xb}\right)$ & -0.2430 \\
\hline \multicolumn{2}{|c|}{ Autocorrelation Test (Wooldridge) } & \multicolumn{2}{|c|}{ Heteroscedasticity Test (Wald } \\
\hline $\mathrm{F}(1,172)$ & 0.920 & Chi2 (232) & $6.4 \mathrm{e}+31$ \\
\hline Prob $>$ F & 0.3387 & Prob $>$ Chi2 & 0.0000 \\
\hline
\end{tabular}

\subsection{Analysis of control variables}

The Equity Equivalence variable (EQUIV) had a coefficient of 3,146,476. A standard deviation of $995,158.80$ is significant in the model, according to the t-test of, 3.16 at the significance level of $1 \%$. This variable that controls the companies' investment activities in controlled and affiliated companies has behaved as expected for the Brazilian market according to Nakao (2012) and Brunozi et al. (2018).

The variable Enterprise Size (SIZE) had a coefficient of $-25,833.58$, a standard deviation of 8,398.82 and representativeness in the model, according to the t-test, of -3.08 at the $1 \%$ significance level. The variable behavior contradicts those determined by studies by Rego (2003), Chen and Zolotoy (2014), Cao and Wan (2014), Gaertner (2014), Chen and Lin (2017), Chen et al. (2019), Chiachio and Martinez (2019), França and Monte (2019). It is possible that managers of smaller companies, with more fragile cost policies, take advantage of investors' focus on large companies, with more developed cost policies, to adopt stronger tax aggressiveness practices and boost their results.

The Return on Assets (ROA) control variable is representative in the model, according to the t-test, with a value of 14.96 at the $1 \%$ significance level. Its coefficient of 5,263.98 and its standard deviation of 351.78 indicate that an increase in profitability increases tax aggressiveness. This result agrees with the premise of a positive relationship between these two variables by McGuire et al. (2014), Chen and Zolotoy (2014), Cao and Wan (2014), Gaertner (2014), Chen et al. (2019), Chiachio and Martinez (2019), França and Monte (2019).

The Variation in Return on Assets (SROA) variable had a coefficient of $-1.21 \mathrm{e}+08$, a standard deviation of $3.76 \mathrm{e}+07$ and a representativeness in the model, according to the $\mathrm{t}$-test, of - 
3.23 at the level of significance 1\%. The variable behaved as expected, according to the studies of Chen and Zolotoy (2014), Gaertner (2014) and Chen et al. (2019). The coefficient indicates that there is a negative relationship between the SROA variable and tax aggressiveness. As the SROA variable indicates the profitability and uncertainty of operations, it can be interpreted that the smaller the variation in profitability, the lower the degree of uncertainty of the operations and the greater the tax aggressiveness. This seems to be evident, as tax aggressiveness is an excellent tool to help boost the result since, as maintaining constant profitability, it makes stocks attractive to investors.

\subsection{Analysis of representative variables of stock liquidity}

The result of the regression in Table 6 indicates that stock liquidity influences tax aggressiveness practices. In general, the result indicates that the more liquid a company's stock is, the more aggressive its tax planning is. This result rejects the hypothesis that market liquidity inhibits tax aggressiveness practices as a greater volume of information on the tax administration of companies with greater shareholder liquidity is required.

As it is a multidimensional construct, the main characteristics of stock liquidity that influenced tax aggressiveness were Volatility (Turnover 1), Merchantability (Exchange Liquidity Index) and Instant Trading Cost (Bid-ask spread). The Exchange Liquidity Index and Bid-ask spread variables behaved contrary to expectations.

The variable Turnover 1 (TUR1) had a coefficient of -0.87 and a standard deviation of 0.18 . This variable was the most representative in the model, with a value of -4.80 based on the $t-$ test, at a significance level of $1 \%$. These results suggest that the mitigating effect of stock liquidity on tax aggressiveness is attenuated for companies with high levels of stock volatility. This corollary corroborates the results proposed by Cao and Wan (2014) and Chen et al. (2019). Thus, companies that have fewer volatile stocks in the market tend to have a more aggressive tax planning.

The Exchange Liquidity Index (LIQB) variable had a coefficient of 86,101.25 and a standard deviation of $30,140.70$. This variable demonstrates relevance in the 2.86 model based on the $\mathrm{t}$-test at the $1 \%$ significance level. This result indicates that companies that have better negotiability indices on the stock exchange, that is, which have a greater relative share of their stock in business conducted at B3, adopt a more aggressive tax planning.

The Bid-ask spread (SPRD) variable, in turn, has an angular coefficient of -13,317.87 and a standard deviation of 4,953.39. This variable is significant in the model, according to the t-test, at -2.69 , whose $\mathrm{p}$-value is $1 \%$. The result indicates that the stocks of companies that have a lower cost of immediate negotiation have greater tax aggressiveness. This metric represents the adverse selection cost, which consists of trading with many stocks, and which have the power to generate falls or increases in the stock price (Menezes da Silva, 2009). This situation tends to occur when new information used by the investor has not yet been reflected in the market price of the stocks, that is, the trader may hold privileged information (Menezes da Silva, 2009).

Bid-ask spread behavior may indicate that managers take advantage of the fact that some negotiators have privileged information and thus leverage the company's results by means of aggressive tax planning, also maximizing their remuneration linked to performance (thus underestimating the agency cost).

In general, managers of companies that have fewer volatile stocks, with greater relative participation in B3's businesses and lower trading costs, tend to adopt a more aggressive tax planning. The results suggest that stock liquidity in the Brazilian stock market does not play a role in repressing information asymmetry. In addition, the principals of the companies in the Brazilian 
stock market seem to underestimate the potential risk of tax assessments in terms of the high negotiability and potential maximization of company results.

\section{FINAL CONSIDERATIONS}

Monitoring shareholders is a necessary tool to inhibit abusive practices by managers, reduce information asymmetry and bring more security to investors. In this context, Chen et al. (2019) have found that the stocks with greater liquidity are from companies that have higher levels of activist shareholders, which provide security to other investors, mitigating information asymmetry and inhibiting tax aggressiveness at its extreme levels.

In this context, this study has investigated the relationship between stock liquidity and tax aggressiveness in companies listed on the Brazilian stock market between 2010 and 2019. We have observed evidence that stock liquidity influences tax aggressiveness practices and that companies with more liquid stocks adopt more aggressive tax planning practices. This behavior is contrary to those found by Cao and Wan (2014) and Chen et al. (2019).

In addition, our results suggests that companies with less volatile stocks, with larger relative stocks in B3 businesses and lower trading costs tend to adopt a more aggressive tax planning. Furthermore, the behavior of the Bid-ask spread variable seems to indicate that some stock traders may have inside information. According to Menezes da Silva (2009), this result may indicate that new information, used by the investor, has not yet been reflected in the market price of the stocks, that is, the trader may hold privileged information.

This study helps to demonstrate that in an emerging capital market such as the Brazilian one investor tend to belittle occasional increases in profits sparingly through more aggressive tax practices, however, which may result in future losses. Furthermore, this study helps to demonstrate the importance of disclosures about tax planning so that market agents can properly price financial assets.

This research is limited to the investigation of the existence of a relationship between tax aggressiveness and stock liquidity and the factors that may imbue this relationship. For future work we suggest that tax aggressiveness be tested with stock liquidity in analyses by quartile according to the levels of tax aggressiveness and by type of stock, common and preferred ones.

\section{REFERENCES}

Almeida Júnior, E. S. (2007). Sistema tributário, governança corporativa e abertura de capital: Brasil versus Estados Unidos. Dissertação de Mestrado, Universidade Federal de Uberlândia.

Amihud, Y. (2002). Illiquidity and stock returns: cross-section and time-series effects. Journal of Financial Markets, 5(1), 31-56.

Al Nasser, O. M., \& Hajilee, M. (2016). Integration of emerging stock markets with global stock markets. Research in International Business and Finance, 36, 1-12.

Amihud, Y., \& Mendelson, H. (2006). Stock and bond liquidity and its effect on prices and financial policies. Financial Markets and Portfolio Management, 20(1), 19-32.

Bebchuk, L. A., \& Weisbach, M. S. (2010). The state of corporate governance research. The review of financial studies, 23(3), 939-961. 
Bhattacharya, N., Desai, H., \& Venkataraman, K. (2013). Does earnings quality affect information asymmetry? Evidence from trading costs. Contemporary Accounting Research, 30(2), 482-516.

Blaylock, B., Shevlin, T., \& Wilson, R. J. (2012). Tax avoidance, large positive temporary booktax differences, and earnings persistence. The Accounting Review, 87(1), 91-120.

Brennan, M. J., Chordia, T., \& Subrahmanyam, A. (1998). Alternative factor specifications, security characteristics, and the cross-section of expected stock returns. Journal of Financial Economics, 49(3), 345-373.

Brunozi, A. C., Kronbauer, C. A., Martinez, A. L., \& Alves, T. W. (2018). BTD anormais, accruals discricionários e qualidade dos accruals em empresas de capital aberto listadas no Brasil. Revista Contemporânea de Contabilidade, 15(35), 108-141.

Cao, S., \& Wan, C. (2014). Stock liquidity and tax avoidance: Evidence from natural experiments.

Carvalho, V. G., Paulo, E., \& Tavares, A. D. L. (2014). Gerenciamento tributário: proxies utilizadas pelas pesquisas no período 2000 a 2012. Registro Contábil, 5(3), 1-19.

Chen, S., Chen, X., Cheng, Q., \& Shevlin, T. (2010). Are family firms more tax aggressive than non-family firms?. Journal of financial economics, 95(1), 41-61.

Chen, T., \& Lin, C. (2017). Does information asymmetry affect corporate tax aggressiveness?. Journal of Financial and Quantitative Analysis, 52(5), 2053-2081.

Chen, Y., Ge, R., Louis, H., \& Zolotoy, L. (2019). Stock liquidity and corporate tax avoidance. Review of Accounting Studies, 24(1), 309-340.

Chen, Y., \& Zolotoy, L. (2014). Stock Liquidity and Corporate Tax-Avoidance: The Tale of Two Tails. School of Accounting Seminar Series, Kensington, NSW, Australia.

Chiachio, V. F. D. O., \& Martinez, A. L. (2019). Efeitos do Modelo de Fleuriet e Índices de Liquidez na Agressividade Tributária. Revista de Administração Contemporânea, 23(2).

Chissom, B. S. (1970). Interpretation of the kurtosis statistic. The American Statistician, 24(4), 1922.

Chung, S. G., Goh, B. W., Lee, J., \& Shevlin, T. (2019). Corporate tax aggressiveness and insider trading. Contemporary Accounting Research, 36(1), 230-258.

Datar, V. T., Naik, N. Y., \& Radcliffe, R. (1998). Liquidity and stock returns: An alternative test. Journal of Financial Markets, 1(2), 203-219.

Famá, E. F., \& French, K. R. (1992). The Cross-section of expected stock returns. Journal of Finance, 47(2), 427-465.

Fávero, L. P. (2015). Análise de dados. (1 ${ }^{\mathrm{a}}$ ed.) Rio de Janeiro. Elsevier. 
Formigoni, H., Antunes, M. T. P., \& Paulo, E. (2009). Diferença entre o lucro contábil e lucro tributável: uma análise sobre o gerenciamento de resultados contábeis e gerenciamento tributário nas companhias abertas brasileiras. BBR-Brazilian Business Review, 6(1), 44-61.

França, R. D. de, \& Monte, P. A. do (2019). Efeitos da remuneração, governança e reputação corporativa na tax avoidance de empresas brasileiras de capital aberto sob a ótica do oportunismo gerencial. Anais do USP International Conference in Accounting, São Paulo.

Frischmann, P. J., Shevlin, T., \& Wilson, R. (2008). Economic consequences of increasing the conformity in accounting for uncertain tax benefits. Journal of Accounting and Economics, 46(2-3), 261-278.

Gaertner, F. B. (2014). CEO after-tax compensation incentives and corporate tax avoidance. Contemporary Accounting Research, 31(4), 1077-1102.

Hanlon, M., \& Heitzman, S. (2010). A Review of tax research. Journal of Accounting and Economics, 50(2-3), 127-178.

Holmström, B., \& Tirole, J. (1993). Market liquidity and performance monitoring. Journal of Political Economy, 101(4), 678-709.

Jayaraman, S., \& Milbourn, T. T. (2012). The Role of stock liquidity in executive compensation. The Accounting Review, 87(2), 537-563.

Kyle, A. S. (1985). Continuous Auctions and Insider Trading. Econometrica, 53(3).

Lahrech, A., \& Sylwester, K. (2011). US and Latin American stock market linkages. Journal of International Money and Finance, 30(7), 1341-1357.

Lesmond, D. A. (2005). Liquidity of emerging markets. Journal of Financial Economics, 77(2), 411-452.

Lisowsky, P., Robinson, L. A., \& Schmidt, A. P. (2013). Do Publicly disclosed tax reserves tell us about privately disclosed tax shelter activity?. Journal of Accounting Research, 51(3).

Machado, M. A. V., \& Medeiros, O. R. (2012). Existe o efeito liquidez no mercado acionário Brasileiro? BBR-Brazilian Business Review, 9(4), 28-51.

Martins, O. S., \& Paulo, E. (2014). Assimetria de informação na negociação de ações, características econômico-financeiras e governança corporativa no mercado acionário brasileiro. Revista Contabilidade \& Finanças, 25(64), 33-45.

Martinez, A. L., \& Leal, L. V. (2019). Conformidade contábil-fiscal e gerenciamento de resultados contábeis no Brasil. RACE-Revista de Administração, Contabilidade e Economia, 18(1), 9-30.

Martinez, A. L., \& Silva, R. F. da (2017). Agressividade Fiscal e o Custo de Capital de Terceiros no Brasil. Revista de Gestão, Finanças e Contabilidade, 7(1), 240-251. 
Martinez, A. L., \& Dalfior, M. D. (2015). Agressividade fiscal entre companhias controladoras e controladas. Revista da Receita Federal: Estudos tributários e aduaneiros, 2(1), 344-362.

Martinez, A. L., \& Martins, V. A. M. (2016). Alavancagem financeira e agressividade fiscal no Brasil. Revista de Contabilidade da UFBA, 10(3), 5-22.

Martinez, A. L., \& Ramalho, V. P. (2017). Agressividade tributária e sustentabilidade empresarial no Brasil. Revista Catarinense da Ciência Contábil, 16(49).

McGuire, S. T., Wang, D., \& Wilson, R. J. (2014). Dual class ownership and tax avoidance. The Accounting Review, 89(4), 1487-1516.

Mclver, R. P., \& Kang, S. H. (2020). Financial crises and the dynamics of the spillovers between the US and BRICS stock markets. Research in International Business and Finance, 54, 101276.

Melo, L. Q., Castro Moraes, G. S., Souza, R. M., \& Nascimento, E. M. (2020). A responsabilidade social corporativa afeta a agressividade fiscal das firmas? Evidências do mercado acionário brasileiro. Revista Catarinense da Ciência Contábil, 19.

Menezes da Silva, R. L. (2009). Divulgação de informações e liquidez de ações: Evidências do setor de Siderurgia e Metalurgia no Brasil. Dissertação de Mestrado, USP.

Mills, L. F. (1998). Book-tax differences and Internal Revenue Service adjustments. Journal of Accounting Research, 36(2), 343-356.

Moraes, G. S. C., Nascimento, E. M., Soares, S. V. N., \& Prímola, B. F. L. (2021). Tax avoidance and tax disclosure: A study of Brazillian listed companies. Contextus - Contemporary Journal of Economics and Management, 19(13), 197-216.

Nakao, S. H. (2012). A adoção de IFRS e o legado da conformidade contábil-fiscal mandatória. Tese de Doutorado, Faculdade de Economia, Administração e Contabilidade de Ribeirão Preto, Universidade de São Paulo.

Oliveira, C. D., Caroli, A. A. de, Amaral, A. S., \& Vilca, O. L. (2014). Detecção de fraudes, anomalias e erros em análise de dados contábeis: Um estudo com base em outliers. Revista Eletrônica do Departamento de Ciências Contábeis \& Departamento de Atuária e Métodos Quantitativos (REDECA), 1(1), 102-127.

Perobelli, F. F. C., Famá, R., \& Sacramento, L. C. (2016). Relações entre liquidez e retorno nas dimensões contábil e de mercado no Brasil. Revista Contabilidade \& Finanças, 27(71).

Rego, S. O. (2003). Tax avoidance activities of US multinational corporations. Contemporary Accounting Research, 20(4), 805-833.

Santos, M. V., Carvalho, H. L. M., \& Ávila, L. A. C. (2019). Complexidade Tributária e Evasão Fiscal no Brasil. Anais do Congresso USP de Iniciação Científica em Contabilidade, São Paulo, 16 
Sarr, A., \& Lybek, T. (2002). Measuring liquidity in financial markets. International Monetary Fund, 2002(232), 1-63.

Scholes, M. S., Wolfson, M. A., Erickson, M., Maydew, E., \& Shevlin, T. (2014). Taxes \& business strategy. Upper Saddle River: Prentice Hall.

Silva, R. L. M. da, Nardi, P. C. C., Martins, V. A., \& Barossi Filho, M. (2016). Os níveis de governança corporativa da BM\&F BOVESPA aumentam a liquidez das ações?. Revista Base (Administração e Contabilidade) da UNISINOS, 13(3), 248-263.

Silveira, V. G. da, Vieira, K. M., Bender Filho, R., \& Coronel, D. A. (2017). Análise fatorial de séries temporais para medidas de liquidez no mercado brasileiro. RACE - Revista de Administração, Contabilidade e Economia, 16(3), 1109-1132.

Slemrod, J., \& Yitzhaki, S. (2002). Tax avoidance, evasion, and administration. In. A. J. Auerbach and F. Feldstein (eds.), Handbook of Public Economics (pp. 1423-1470).

Tôrres, H. T. (2001). Direito tributário internacional: Planejamento tributário e operações transnacionais. São Paulo: Revista dos Tribunais.

Tukey, J. W. (1962). The Future of data analysis. The Annals of mathematical statistics, 33(1), 167.

Vello, A. P. C., \& Martinez, A. L. (2014). Planejamento tributário eficiente: uma análise de sua relação com o risco de mercado. Revista Contemporânea de Contabilidade, 11(23).

Vieira, K. M., Justen Júnior, A. A., \& Righi, M. B. (2015). O papel da liquidez e suas múltiplas dimensões no retorno das ações: Um estudo com dados em painel do mercado brasileiro. CONTEXTUS - Revista Contemporânea de Economia e Gestão, 13(2), 7-34.

Vieira, K. M., \& Milach, F. T. (2008). Liquidez/iliquidez no mercado brasileiro: Comportamento no período 1995-2005 e suas relações com o retorno. Revista Base, 5(1).

Wahab, N. S. A., \& Holland, K. (2012). Tax Planning, corporate governance, and equity value. The British Accounting Review, 44(2), 111-124. 